\section{Comparison of NAA and Carbaryl Petal- fall Sprays on Fruit Set of Apples}

\author{
Max W. Williams ${ }^{1}$
}

Additional index words. fruit, biennial bearing, postbloom, chemical thinners, naphthalene acetic acid, 1naphthyl-N-methylcarbamate

Summary. Biennial bearing of apple trees can be overcome either by the use of a blossom chemical thinner or by early application of a postbloom thinner. Carbaryl (Sevin) is a postbloom fruit-thinning chemical with an effective thinning period of 4 to 5 weeks after bloom. Sevin was compared in 1992 and 1993 with NAA as an early petal-fall spray. Sevin treatments reduced fruit set to one fruit per cluster with no adverse side effects on the foliage. NAA inconsistently reduced fruit set and the remaining fruit were in clusters, The NAAtreated foliage was adversely affected; having small curled leaves. NAA at 10 ppm under-thinned in 1992 and seriously over-thinned in 1993, whereas Sevin treatments were consistent for fruit thinning in both years. Sevin applied at petal-fall or at petal-fall +7 days effectively reduced fruit set and reduced fruit competition.

$\mathrm{P}$ ostbloom sprays of NAA and carbaryl (Sevin) are used for reducing fruit set of apples ( Malus domestica Borkh.) The usual time of chemical application is when the largest fruit are 10 to $15 \mathrm{~mm}$ in diameter (Williams and Edgerton, 1981). Ap-

\footnotetext{
U.S. Department of Agriculture, Agricultural Research Service, Tree Fruit Research Laboratory, 1104 N. Westcm Avenue, Wenatchee, WA 98801.

Use of a company or product name by the USDA does not imply approval or recommendation of the product to the exclusion of others that may also be suitable. The cost of publishing- this paper was defrayed in part by the payment of page charges. Under postal regulations, this paper therefore must hereby be marked advertisement solely to indicate this fact.

${ }^{\prime}$ Plant Physiologist.
}

plication of sprays at the 10 - to $15-\mathrm{mm}$ fruit diameter stage takes advantage of warm weather conditions after spraying, thus increasing stress and reducing fruit set with a minimum effect on the seed number in the persisting fruit (Williams, 1989).

Elgetol, a blossom-thinning agent, was used previously in Washington and other western states before postbloom application NAA and Sevin, and there was no need for earlier timing of the NAA and Sevin sprays. In 1989, Elgetol was removed from the marlcet by the manufacturer because of the high cost of re-registration. Without a blossom thinner or an early petal-fall spray there is no guarantee for a return bloom on severely biennial-bearing cultivars, even when adequate fruit thinning occurs with the later postbloom thinning sprays. Both NAA and Sevin are effective fruit thinners over a period of 4 to 5 weeks after full bloom (Batjer and Hoffman, 1968; Donoho, 1988; Washington State University, 1993; Williams and Batjer, 1964; Williams and Edgerton, 1981).

Early applications of NAA or Sevin at the petal-fall stage have not been evaluated thoroughly. This report compares the efficacy of the postbloom thinners NAA and Sevin as early petal fall sprays for reducing fruit set.

\section{Methods}

In 1992, two different thinning trials were conducted on 'Delicious', one at Wenatchee, Wash., and one in a commercial orchard at Quincy, Wash. The XLR Plus flowable 50\% a.i. Sevin and the $\mathrm{K}$ salt of naphthalene acetic acid (NAA) were used in all trials. Regulaid, a non-ionic surfactant, was used with NAA at a rate of $0.125 \%$ (v/ $v)$. The chemical rates used on 'Delicious' are shown in Tables 1 and 2 . Sulfcarbamide (D-88), 79\% a.i., was included as a full-bloom spray in the Quincy trial. The chemical rate used on 'Fuji' apples are shown in Table 3.

In the Wenatchee trials, three uniform full-bloom trees of 14-yearold 'Oregon Spur Delicious' on M7 rootstock were selected. The number of blossom clusters on each of three limbs per tree were counted and recorded. In the Quincy trial, two limbs were counted on each of 10 trees of 'Oregon Spur Delicious' per treatment. The Wenatchee treatments were applied at full-bloom or at early petal-fall as full-volume sprays with a high-pressure hand gun, and the Quincy treatments were applied at early petal-fall with a commercial air-blast sprayer. After fruit abscission, » 6 weeks after bloom, the number of fruit remaining on the previously counted limbs were counted and recorded. Data were subjected to analysis of variance, and means within treatments were compared using Wailer-Duncan $\mathrm{K}$ ratio $t$ test at a $=0.05$ (SAS Institute, 1987). Fruit set is expressed in the tables as the number of fruit per 100 blossom clusters and as percentage fruit set relative to the control. Seed number per fruit and average number of fruit per cluster were determined after natural fruit drop was complete.

The 1993 trials were conducted to confirm the 1992 results using the same methods as in 1992 Wenatchee trials. The cultivars Fuji, Granny Smith, and Delicious were included in the 1993 trials. Sprays were applied at petal-fall and 1 week later when king fruit were $5 \mathrm{~mm}$ in diameter.

\section{Results}

NAA at $5 \mathrm{ppm}+$ Regulaid slightly increased fruit drop, but at the 10ppm rate, NAA significantly increased thinning (Table 1). Sevin caused significant fruit drop on 'Delicious' and 'Fuji' (Tables 1-3). The petal-fall time application of Sevin was more effective than the full-bloom rime of application. A particularly noteworthy observation was the Sevin petal-fall treat-

Table 1. Effect of early sprays of NAA or Sevin on fruit set of 'Delicious' apples, Wenatchee, Wash., 1992.

\begin{tabular}{|c|c|c|}
\hline Treatment $t^{*}$ & $\begin{array}{c}\text { Fruit set/100 } \\
\text { blossom clusters }\end{array}$ & Control (\%) \\
\hline $\begin{array}{l}\text { Control } \\
\text { NAA } 5 \mathrm{ppm}+\end{array}$ & $65 a^{y}$ & 100 \\
\hline $\begin{array}{l}\text { Reg. PF } \\
\text { NAA } 10 \text { ppm }\end{array}$ & $54 a-c$ & 83 \\
\hline $\begin{array}{c}+ \text { Reg. PF } \\
\text { Sevin } 0.125 \%\end{array}$ & $50 c-f$ & 77 \\
\hline $\begin{array}{c}(v / v) \text { FB } \\
\text { Sevin } 0.188 \%\end{array}$ & $52 \mathrm{~b}-\mathrm{d}$ & 80 \\
\hline $\begin{array}{l}(v / v) F B \\
\text { Sevin } 0.125 \%\end{array}$ & $43 c-f$ & 66 \\
\hline $\begin{array}{c}(v / v) P F \\
\text { Sevin } 0.188 \%\end{array}$ & $38 \mathrm{ef}$ & 59 \\
\hline$(v / v) P F$ & $35 \mathrm{f}$ & 54 \\
\hline
\end{tabular}


Table 2. Comparison of petal-fall sprays of Sevin, NAA, and D-88 on 'Delicious' apples, Quincy, Wash., 1992.

\begin{tabular}{lcc}
\hline & $\begin{array}{c}\text { Fruit set/100 } \\
\text { blossom clusters }\end{array}$ & Control (\%) \\
Treatment $^{z}$ & $73 \mathrm{a}^{\mathrm{y}}$ & 100 \\
\hline $\begin{array}{l}\text { Control } \\
\text { NAA.5 ppm }\end{array}$ & $56 \mathrm{~b}$ & 77 \\
PF & & \\
$\begin{array}{l}\text { Sevin } 0.188 \% \\
(\mathrm{v} / \mathrm{v}) \mathrm{PF}\end{array}$ & $52 \mathrm{bc}$ & 71 \\
$\begin{array}{l}\text { D-88 0.375\% } \\
(\mathrm{v} / \mathrm{v}) \mathrm{FB}\end{array}$ & $40 \mathrm{c}$ & 55
\end{tabular}

${ }^{*} F B=$ full bloom, $P F=$ petal-fall.

${ }^{y}$ Treatmentswith common lettersare not different by Waller-Duncan K ratio t test.

Table 3. Effect of petal-fall sprays of Sevin on 'Fuji' apples, 1992.

\begin{tabular}{lcc}
\hline & $\begin{array}{c}\text { Fruit set/100 } \\
\text { blossom clusters }\end{array}$ & Control (\%) \\
Treatment $^{2}$ & $74 \mathrm{a}^{\mathrm{y}}$ & 100 \\
\hline $\begin{array}{l}\text { Control } \\
\text { Sevin } 0.188 \% \\
(\mathrm{v} / \mathrm{v}) \mathrm{PF}\end{array}$ & $45 \mathrm{c}$ & 61 \\
\hline "PF = petal-fall. \\
$\begin{array}{l}\text { "Treatmentswith common lettersare notdifferent } \\
\text { by Waller-Duncan K ratio t test. }\end{array}$
\end{tabular}

ments reduced fruit number to one per cluster, compared with two to three fruit per cluster for NAA (Table 4).

Table 4. Seed number per fruit after NAA or Sevin petal-fall sprays on 'Delicious' apples, Wenatchee, Wash., 1992

\begin{tabular}{lcc}
\hline Treatment & $\begin{array}{c}\text { No. seed/ } \\
\text { fruit }\end{array}$ & $\begin{array}{c}\text { Avg. no. fruit/ } \\
\text { cluster }\end{array}$ \\
\hline $\begin{array}{l}\text { Control } \\
\text { NAA 5 ppm + }\end{array}$ & $5.5 \mathrm{c}^{\mathrm{y}}$ & $3.5 \mathrm{~cd}^{\mathrm{x}}$ \\
$\quad$ Reg. PF & $2.3 \mathrm{~d}$ & $3.0 \mathrm{c}$ \\
$\begin{array}{l}\text { NAA 10 ppm + } \\
\text { Reg. PF }\end{array}$ & $3.5 \mathrm{e}$ & $2.8 \mathrm{bc}$ \\
$\begin{array}{l}\text { Sevin 0.188\% } \\
(\mathrm{v} / \mathrm{v}) \mathrm{FB}\end{array}$ & $7.5 \mathrm{a}$ & $1.5 \mathrm{~b}$ \\
$\begin{array}{l}\text { Sevin 0.188\% } \\
(\mathrm{v} / \mathrm{v}) \mathrm{PF}\end{array}$ & $6.8 \mathrm{~b}$ & $1.0 \mathrm{a}$ \\
$\begin{array}{l}\mathrm{D}-880.375 \% \\
(\mathrm{v} / \mathrm{v}) \mathrm{FB}\end{array}$ & $6.7 \mathrm{~b}$ & $2.0 \mathrm{bc}$ \\
\hline
\end{tabular}

${ }^{2} F B=$ full bloom, $P F=$ petal-fall.

${ }^{y}$ Average for 100 fruit per treatment.

"Aperage number of fruit after "June drop." Treatments with common letters are not different by the Waller-Duncan K ratio t test.

Table 5. Effect of early sprays of Sevin on fruit set of apples, 1993.

\begin{tabular}{llcc}
\hline & \multicolumn{3}{c}{ Fruit set/100 blossom clusters } \\
\cline { 2 - 4 } Cultivar and rate & Petal-fall & Petal-fall + 7 days & Control \\
\hline Delicious, $0.188 \%(\mathrm{v} / \mathrm{v})$ & $44 \mathrm{~b}^{\mathrm{z}}$ & $54 \mathrm{~b}$ & $86 \mathrm{a}$ \\
Granny Smith, $0.188 \%(\mathrm{v} / \mathrm{v})$ & $62 \mathrm{~b}$ & $48 \mathrm{c}$ & $84 \mathrm{a}$ \\
Fuji, $0.188 \%(\mathrm{v} / \mathrm{v})$ & $51 \mathrm{~b}$ & $66 \mathrm{~b}$ & $98 \mathrm{a}$ \\
\hline${ }^{\text {sTreatments with common letters are not different by the Waller-Duncan K ratio }}$ \\
test.
\end{tabular}

The seed number per fruit was not reduced with Sevin, whereas with NAA both the 5- and 10-ppm rates reduced seed numbers (Table 4). The kingbloom fruit remained, and the sidebloom fruit were removed by the Sevin sprays. In contrast to Sevin, which reduced fruit to one per cluster, NAA removed fruit indiscriminately and the fruit remained in clusters. The foliage of the Sevin-treated trees was not affected, whereas the NAA treatments tended to curl the leaves inward and reduced leaf size. Return bloom on all 1992 sprayed plots was adequate (50\% to $65 \%$ ) for a crop in 1993.

Fruit-thinning of the apple cultivars treated in 1993 was significant (Table 5). The early post-bloom sprays were effective for a period of 7 to 10 days after bloom (Table 5). In 1993, NAA at $10 \mathrm{ppm}$ caused over-thinning and had a more-pronounced effect on leaf size and leaf curling than in 1992. The persisting fruit on the NAA trees were small, with pinched caylx ends. The 1993 Sevin treatments on 'Delicious' reduced fruit set to one per cluster and did not adversely affect the foliage. Fruit set on 'Granny Smith' and 'Fuji' after Sevin treatment was one, two, or three fruit per cluster, depending on spur vigor. The daytime temperatures following the treatments in 1993 were from 30 to $37 \mathrm{C}$ and some weak spurs and limbs on 'Delicious' were overthinned by the Sevin applications.

\section{Conclusions}

Both Sevin and NAA applied at petal-fall reduced fruit set. Undesirable side effects such as low seed num- ber, small fruit size, poor fruit shape, and foliage curling were observed in NAA treatments. None of the above effects were noted with Sevin, and the reduction of set to one fruit per cluster was desirable. Sevin applied later than petal-fall may cause seed abortion unless the temperature is high enough to cause fruit with aborted seeds to abscise (Washington State Univ., 1993; Williams, 1989; Williams and Edgerton, 1981).

\section{Literature Cited}

Batjer, L.P. and M.B. Hoffman. 1968. Effectiveness of thinning sprays as related to fruit size at time of spray application. Proc. Amer. Soc. Hort. Sci. 92:50-54.

Donoho, C.W., Jr. 1988. The relationship of date ofapplication and size of fruit to the effectiveness of NAA for thinning apples. Proc. Amer. Soc. Hort. Sci. 92:55-62.

SAS Institute. 1987. SAS/stat guide for personal computers. Vers. 6 ed. SAS Institute, Inc. Cary, N.C.

Washington State University. 1993. Crop protection guide for tree fruits in Washington. Ext. Bul. EB 0419.

Williams, M.W. 1989. Control of flowering, fruit set, and seed development in apple with chemical growth regulators. Acta Hort. 240:221-228.

William, M.W. and L.P. Batjer. 1964. Site and mode of action of 1-naphthyl-Nmethylcarbamate (Sevin) in thinning apples. Proc. Amer. Soc. Hort. Sci. 85:1-10

Williams, M.W. and L.J. Edgerton. 1981. Fruit thinning of apples and pears with chemicals. USDA Agr. Bul. 289. 